\section{Tinjauan Yuridis Terhadap Tindak Pidana \\ Kepemilikan Senjata Api Tanpa Hak Oleh \\ Masyarakat Sipil (Putusan Nomor : \\ 79/PID.B/2016/PN.BLG)}

Oleh :

\section{Sonya Airini Batubara ${ }^{1}$}

Tim :

\section{(Suganda Kelima Siregar², Christin Yulia Simatupang ${ }^{3}$ )}

\begin{abstract}
This study aims to find out how the criminal liability for abuse of firearms is. This study applies normative research method in which the research is conducted based on reading materials such as books, literature and legislation relating to the material to be discussed in this thesis. From the results of the study, it can be concluded that the act of abuse of firearms is that it has become a lifestyle, and causes a sense of self security because of the increasingly widespread circulation of illegal firearms in Indonesia. But the security of our society can actually be disrupted if they are unable to hold back their emotions and are less responsible.
\end{abstract}

Keywords: Abuse, Firearms, Civil Society

\begin{abstract}
Abstrak
Penelitian ini bertujuan untuk mengetahui bagaimana bentuk Pertanggungjawaban Pidana atas penyalahgunaan senjata api. Penelitian ini menggunakan metode penelitian normatif adalah penelitian yang dilakukan berdasarkan bahan-bahan bacaan, dengan cara membaca buku-buku, literatur-literatur serta peraturan perundang-undangan yang berhubungan dengan materi yang akan dibahas dalam skripsi ini. Dari hasil penelitian disimpulkan bahwa tindak penyalahgunaan senjata api yang terjadi yaitu telah menjadi gaya hidup selain itu untuk menimbulkan rasa aman bagi diri sendiri karena makin maraknya peredaran senjata api
\end{abstract}

ilegal di Indonesia. Namun masyarakat kita justru bisa tergganggu keamanannya jika mereka tidak mampu menahan emosinya dan kurang bertanggung jawab.

Kata Kunci ; Penyalahgunaan, Senjata Api, Masyarakat Sipil

\section{PENDAHULUAN}

\section{A. Latar Belakang}

Negara Indonesia dalam hal ini menganut sistem demokrasi.Istilah demokrasi yang diartikan sebagai pemerintahan atau kekuasaan dari rakyat oleh rakyat dan untuk rakyat. Namun demikian penerapan demokrasi diberbagai negara di dunia, memiliki ciri khas dan spesifikasi masing-masing, yang lazimnya sangat dipengaruh oleh ciri khas masyarakat sebagai rakyat dalam suatu negara. ${ }^{1}$

Negara Indonesia sendiri tidak terlepas dari berbagai macam masalah seperti yang penulis lihat dalam beberapa tahun terakhir begitu banyaknya dan bertambahnya aksi kriminalitas yang disebabkan oleh bertambahnya pertumbuhan penduduk yang tidak diimbangi dengan jumlah lowongan pekerjaan mengakibatkan masih banyak penduduk di Indonesia yang hidup dengan keadaan ekonomi yang menengah kebawah. ${ }^{2}$ Berdasarkan ketentuan yang berlaku, izin kepemilikan senjata api di Indonesia dibatasi hingga satu tahun dan dapat diperpanjang dalam jangka waktu yang sama.

${ }^{1} \mathrm{H}$. Hari Saherodji, Pokok-pokok Kriminiologi, Aksara Baru, Jakarta, hal 11

${ }^{2}$ Soerjono soekanto.Faktor-faktor yang mempengaruhi penegakan hukum. Jakarta.Rineka Cipta.1986.hlm.25 
Media Komunikasi dan Informasi Hukum dan Masyarakat

Berdasarkan latar belakang yang diuraikan diatas, maka penulis tertarik untuk meneliti dan menuangkan dalam tulisan penelitian hukum dengan judul : "Tinjauan Yuridis Terhadap Tindak Pidana Kepemilikan Senjata Api Tanpa Hak Oleh Masyarakat Sipil (Tinjauan Kasus NO.79/PID.B/2016/PN.BLG)".

\section{B. Perumusan Masalah}

Berdasarkan uraian latar belakang tersebut, maka penulis merumuskan pemasalahan sebagai berikut, yaitu :

1. Bagaimana penerapan hukum terhadap kepemilikan senjata api oleh masyarakat sipil?

2. Bagaimana kebijakan hukum dalam penanganan tindak pidana kepemilikan senjata api oleh masyarakat sipil?

3. Bagaimana pertimbangan hakim dalam memberikan putusan terhadap tindak pidana kepemilikan senjata api oleh masyarakat sipil dalam putusan no.79/Pid.B/2016/PN.Blg?

\section{METODE PENELITIAN}

\section{Jenis dan Sifat Penelitian}

Penulisan penelitian hukum (skripsi) dengan judul "Tinjauan Yuridis Terhadap Tindak Pidana Kepemilikan Senjata Api Tanpa Hak Oleh Masyarakat Sipil", ini termasuk penelitian yuridis normatif yang juga biasa disebut sebagai penelitian kepustakaan atau studi dokumen. Disebut penelitian hukum yuridis normatif karena penelitian ini dilakukan atau ditujukan pada peraturan-peraturan yang tertulis atau bahan hukum-hukum yang lain. Disebut penelitian kepustakaan disebabkan penelitian lebih banyak dilakukan terhadap bahan yang bersifat sekunder yang ada diperpustakaan.

Penelitian yuridis normatif dilakukan dengan cara menelaah dan menginterpretasikan hal-hal yang bersifat teoritis yang menyangkut asas, konsepsi, doktrin dan norma hukum yang berkaitan dengan pembuktian perkara pidana.

Penelitian yuridis normatif adalah pendekatan yang dilakukan berdasarkan bahan hukum utama dengan cara menelaah teori-teori, konsep-konsep, asas-asas hukum serta peraturan perundang-undangan yang berhubungan dengan penelitian ini. Pendekatan ini dikenal dengan pendekatan kepustakaan, yakni dengan mempelajari buku-buku, peraturan perundang-undangan dan dokumen lain yang berhubungan dengan penelitian ini.

\section{Sumber Bahan Hukum}

Dalam penelitian hukum normatif bahan pustaka merupakan dasar yang dalam (ilmu) penelitian digolngkan sebagain data sekunder. Data skunder dalam penelitian ini dapat dibedakan menjadi 3 :

a. Bahan hukum primer

Bahan hukum primer didalam penelitian ini adalah bahan hukum yang kekuatannya mengikat, yakni ;

a. Kitab Undang-Undang Hukum Pidana (KUHP),

b. Undang-Undang Nomor 12 tahun 1951 Tentang pengaturan senjata api,

c. UU No. 2 Tahun 2002 tentang Kepolisian Negara Republik Indonesia,dan

d. Skep Kapolri No. Pol: Skep / 82 / II / 2004 tentang Pelaksanaan Pengawasan dan Pengendalian Senjata Non Organik TNI / POLRI

b. Bahan Hukum Skunder

Bahan Hukum Sekunder berupa pendapat para ahli, teori-teori yang dapat membantu mengungkap masalah dalam peneiitian ini, Rancangan Kitab UndangUndang Hukum Pidana (RKUHP), hasil- 
Media Komunikasi dan Informasi Hukum dan Masyarakat

hasil peneiitian terdahulu yang berhubungan dengan pertanggungjawaban tindak pidana penyalahgunaan senjata api oleh masyarakat, putusan pengadilan yang telah mempunyai kekuatan hukum tetap, pendapat para ahli/pakar hukum yang berhubungan dengan pertanggungjawaban tindak pidana penyalahgunaan Senjata Api iiegal yang dilakukan oleh masyarakat sipil.

c. Bahan Hukum Tersier

Merupakan bahan yang memberikan penjelasan mengenai bahan hukum primer dan bahan hukum skunder, seperti kamus, ensiklopedia, serta artikel dari internet.

\section{Teknik Pengumpulan Data}

Karena dengan jenis penelitian yang digunakan adalah yuridis normatif, maka dalam metode pengumpulan data yang digunakan adalah studi kepustakaan. Studi kepustakaan adalah segala usaha yang dilakukan oleh peneliti untuk menghimpun informasi yang relevan dengan topik atau masalah yang akan atau sedang diteliti. Informasi itu dapat diperoleh dari buku-buku ilmiah, laporan penelitian, karangan-karangan ilmiah, tesis dan disertasi, peraturan-peraturan, ketetapan-ketetapan, buku tahunan, ensiklopedia, dan sumber-sumber tertulis baik tercetak maupun elektronik.

Dilakukan juga dengan pengumpulan data sekunder yaitu dengan cara membaca dan mempelajari artikel-artikel pada majalahmajalah, tabloid-tabloid, surat kabar dan bukubuku bacaan lainnya dan peraturan perunangundangan atau referensi lainnya yang erat kaitannya dengan permasalahan yang dibahas.

\section{Analisis Data}

Dalam penelitian ini analisis data yang digunakan adalah analisis secara kualitatif yaitu uraian yang dilakukan peneliti terhadap data yang terkumpul tidak menggunakan statistik atau matematika ataupun sejenisnya, tetapi berupa uraian -uraian kalimat yang tersusun secara sistematis sesuai dengan permasalahan yang dibahas. Dalam narik kesimpulan penulis menggunakan mtode berfikir dedukatif yaitu cara berfikiyang menarik kesimpulan dari suatu pernataan atau dalil yang bersifat umum menadi suatu pernyataan yang bersifat khusu

\section{HASIL DAN PEMBAHASA}

\section{A. Penerapan Hukum Terhadap Kepemilikan} Senjata Api

1. Penerapan Hum Terhadap Kepemilikan Senjata Api Oleh Masyarakat

Faktor kurangnya kesadaran masyarakat untuk menyerahkan senjata api illegal kepada aparat penegak hukum sering kali menjadi kendala dalam menanggulangi peredaran senjata api illegal di masayarakat. Sering kali dijumpai masyarakat yang dirumah dan tempat tinggalnya menyimpan senjata api illegal.

Awalnya masyarakat dahulu memiliki dan menyimpan senjata api ilegal adalah untuk pengamanan diri, jika sewaktu-waktu berhadapan dengan hal yang mengancam jiwanya, untuk mempertahankan diri saat terjadi kerusuhan antar etnis. Senjata api dapat digunakan untuk perlindungan diri dari aksi kejahatan karena semakin maraknya kejahatan dengan senjata api, namun, ada aturan menggunakan senjata api. Meskipun dibolehkan, warga sipil tidak boleh menggunakannya jika tidak dibutuhkan. Aturan pertama yaitu senpi yang dimiliki tidak boleh 
Media Komunikasi dan Informasi Hukum dan Masyarakat

dipertontonkan di depan umum apalagi untuk menakut-nakuti orang lain. ${ }^{3}$

Prosedur izin kepemilikan senjata api bagi masyarakat sipil ini diatur pada Peraturan Kapolri Nomor 8 Tahun 2012 tentang Pengawasan dan Pengendalian Senjata Api untuk Kepentingan Olahraga dan Buku Petunjuk Pelaksanaan Pengawasan dan Pengendalian Senjata Api pada Surat Keputusan kapolri Nomor Polisi : Skep/82/II/2004. ${ }^{4}$

\section{Penerapan Hukum Terhadap Kepemilikan Senjata Api Oleh Angkatan POLRI dan TNI}

Sebagian masyarakat di Indonesia berpendapat bahwa keamanan terhadap warga sipil masih belum maksimal sebagaimana mestinya, hal ini dapat di lihat sekarang banyak warga sipil yang memiliki senjata api. Bagi seseorang yang ingin menjaga keselamatan diri dengan memiliki senjata bukan lah suatu tindakan yang tidak baik. Sebab, kepemilikan senjata api itu telah diatur oleh Undang undang Nomor 12 tahun 1951 dan didukung Undang - undang Nomor 20 Prp tahun 1960 tentang kewenangan perizinan senjata api, tentang Kepolisian Republik Indonesia UndangUndang Nomor: 2 tahun 2002 menjelaskan di dalam Pasal 15 ayat 2 huruf e yakni Kepolisian memberikan izin dan melakukan pengawasan senjata api, bahan peledak, dan senjata tajam. Administrasi pada lembaga kepolisian dalam hal perizinan senjata api itu sendiri adalah bagian

${ }^{3} \mathrm{http}: / /$ batamnews.co.id/berita-14331inilah-syarat-memiliki-senjata-api-bagi-wargasipil-di-indonesia.html, diakses tanggal 07 November 2018

${ }^{4}$ Anak Agung Ngurah Bayu Ariadi,Pertanggung jawaban pidana atas penylahgunaan senjata api, Jurnal Fakultas Hukum Universitas Udayana,2013, hal 11 dari administrasi negara dan sistem kepolisian suatu negara sangat terpengaruh dan bergantung dari bagaimana sistem pemerintahan suatu negara itu sendiri berjalan. ${ }^{5}$

Selain itu, setelah menggunakan senjata api, polisi harus membuat laporan terperinci mengenai evaluasi pemakaian senjata api. Laporan tersebut berisi (Pasal 14 ayat (2) Perkapolri 1/2009). Laporan inilah yang akan digunakan untuk bahan pertanggungjawaban hukum penerapan penggunaan kekuatan, serta sebagai bahan pembelaan hukum dalam hal terjadi gugatan pidana/perdata terkait penggunaan kekuatan yang dilakukan oleh anggota Polri yang bersangkutan (Pasal 14 ayat (5) huruf 3 dan f Perkapolri 1/2009).

Pada prinsipnya, setiap anggota POLRI wajib bertanggung jawab atas pelaksanaan penggunaan kekuatan (senjata api) dalam tindakan kepolisian yang dilakukannya (Pasal 13 ayat (1) Perkapolri 1/2009).

\section{Perumusan Masalah}

Berdasarkan uraian latar belakang tersebut, maka penulis merumuskan pemasalahan sebagai berikut, yaitu :

4. Bagaimana penerapan hukum terhadap kepemilikan senjata api oleh masyarakat sipil?

5. Bagaimana kebijakan hukum dalam penanganan tindak pidana kepemilikan senjata api oleh masyarakat sipil?

6. Bagaimana pertimbangan hakim dalam memberikan putusan terhadap tindak pidana kepemilikan senjata api oleh masyarakat sipil dalam putusan no.79/Pid.B/2016/PN.Blg?

${ }^{5}$ Awaloedin, Djamin.sistem Administrasi Kepolisian.(Jakarta:YPKIK,2011),hal 5 
Media Komunikasi dan Informasi Hukum dan Masyarakat

\section{E. METODE PENELITIAN}

\section{Jenis dan Sifat Penelitian}

Penulisan penelitian hukum (skripsi) dengan judul "Tinjauan Yuridis Terhadap Tindak Pidana Kepemilikan Senjata Api Tanpa Hak Oleh Masyarakat Sipil", ini termasuk penelitian yuridis normatif yang juga biasa disebut sebagai penelitian kepustakaan atau studi dokumen. Disebut penelitian hukum yuridis normatif karena penelitian ini dilakukan atau ditujukan pada peraturan-peraturan yang tertulis atau bahan hukum-hukum yang lain. Disebut penelitian kepustakaan disebabkan penelitian lebih banyak dilakukan terhadap bahan yang bersifat sekunder yang ada diperpustakaan.

Penelitian yuridis normatif dilakukan dengan cara menelaah dan menginterpretasikan hal-hal yang bersifat teoritis yang menyangkut asas, konsepsi, doktrin dan norma hukum yang berkaitan dengan pembuktian perkara pidana.

Penelitian yuridis normatif adalah pendekatan yang dilakukan berdasarkan bahan hukum utama dengan cara menelaah teori-teori, konsep-konsep, asas-asas hukum serta peraturan perundang-undangan yang berhubungan dengan penelitian ini. Pendekatan ini dikenal dengan pendekatan kepustakaan, yakni dengan mempelajari buku-buku, peraturan perundang-undangan dan dokumen lain yang berhubungan dengan penelitian ini.

\section{Sumber Bahan Hukum}

Dalam penelitian hukum normatif bahan pustaka merupakan dasar yang dalam (ilmu) penelitian digolngkan sebagain data sekunder. Data skunder dalam penelitian ini dapat dibedakan menjadi 3 :

d. Bahan hukum primer
Bahan hukum primer didalam penelitian ini adalah bahan hukum yang kekuatannya mengikat, yakni ;

e. Kitab Undang-Undang Hukum Pidana (KUHP),

f. Undang-Undang Nomor 12 tahun 1951 Tentang pengaturan senjata api,

g. UU No. 2 Tahun 2002 tentang Kepolisian Negara Republik Indonesia,dan

h. Skep Kapolri No. Pol: Skep / 82 / II / 2004 tentang Pelaksanaan Pengawasan dan Pengendalian Senjata Non Organik TNI / POLRI

e. Bahan Hukum Skunder

Bahan Hukum Sekunder berupa pendapat para ahli, teori-teori yang dapat membantu mengungkap masalah dalam peneiitian ini, Rancangan Kitab UndangUndang Hukum Pidana (RKUHP), hasilhasil peneiitian terdahulu yang berhubungan dengan pertanggungjawaban tindak pidana penyalahgunaan senjata api oleh masyarakat, putusan pengadilan yang telah mempunyai kekuatan hukum tetap, pendapat para ahli/pakar hukum yang berhubungan dengan pertanggungjawaban tindak pidana penyalahgunaan Senjata Api iiegal yang dilakukan oleh masyarakat sipil.

f. Bahan Hukum Tersier

Merupakan bahan yang memberikan penjelasan mengenai bahan hukum primer dan bahan hukum skunder, seperti kamus, ensiklopedia, serta artikel dari internet.

\section{Teknik Pengumpulan Data}

Karena dengan jenis penelitian yang digunakan adalah yuridis normatif, maka dalam metode pengumpulan data yang digunakan 
Media Komunikasi dan Informasi Hukum dan Masyarakat

adalah studi kepustakaan. Studi kepustakaan adalah segala usaha yang dilakukan oleh peneliti untuk menghimpun informasi yang relevan dengan topik atau masalah yang akan atau sedang diteliti. Informasi itu dapat diperoleh dari buku-buku ilmiah, laporan penelitian, karangan-karangan ilmiah, tesis dan disertasi, peraturan-peraturan, ketetapan-ketetapan, buku tahunan, ensiklopedia, dan sumber-sumber tertulis baik tercetak maupun elektronik.

Dilakukan juga dengan pengumpulan data sekunder yaitu dengan cara membaca dan mempelajari artikel-artikel pada majalahmajalah, tabloid-tabloid, surat kabar dan bukubuku bacaan lainnya dan peraturan perunangundangan atau referensi lainnya yang erat kaitannya dengan permasalahan yang dibahas.

\section{Analisis Data}

Dalam penelitian ini analisis data yang digunakan adalah analisis secara kualitatif yaitu uraian yang dilakukan peneliti terhadap data yang terkumpul tidak menggunakan statistik atau matematika ataupun sejenisnya, tetapi berupa uraian -uraian kalimat yang tersusun secara sistematis sesuai dengan permasalahan yang dibahas. Dalam narik kesimpulan penulis menggunakan mtode berfikir dedukatif yaitu cara berfikiyang menarik kesimpulan dari suatu pernataan atau dalil yang bersifat umum menadi suatu pernyataan yang bersifat khusu

\section{HASIL DAN PEMBAHASA}

\section{B. PENERAPAN HUKUM TERHADAP KEPEMILIKAN SENJATA API}

\section{Penerapan Hum Terhadap Kepemilikan} Senjata Api Oleh Masyarakat
Faktor kurangnya kesadaran masyarakat untuk menyerahkan senjata api illegal kepada aparat penegak hukum sering kali menjadi kendala dalam menanggulangi peredaran senjata api illegal di masayarakat. Sering kali dijumpai masyarakat yang dirumah dan tempat tinggalnya menyimpan senjata api illegal.

Awalnya masyarakat dahulu memiliki dan menyimpan senjata api ilegal adalah untuk pengamanan diri, jika sewaktu-waktu berhadapan dengan hal yang mengancam jiwanya, untuk mempertahankan diri saat terjadi kerusuhan antar etnis. Senjata api dapat digunakan untuk perlindungan diri dari aksi kejahatan karena semakin maraknya kejahatan dengan senjata api, namun, ada aturan menggunakan senjata api. Meskipun dibolehkan, warga sipil tidak boleh menggunakannya jika tidak dibutuhkan. Aturan pertama yaitu senpi yang dimiliki tidak boleh dipertontonkan di depan umum apalagi untuk menakut-nakuti orang lain. ${ }^{6}$

Prosedur izin kepemilikan senjata api bagi masyarakat sipil ini diatur pada Peraturan Kapolri Nomor 8 Tahun 2012 tentang Pengawasan dan Pengendalian Senjata Api untuk Kepentingan Olahraga dan Buku Petunjuk Pelaksanaan Pengawasan dan Pengendalian Senjata Api pada Surat Keputusan kapolri Nomor Polisi : Skep/82/l1/2004.7
${ }^{6} \mathrm{http}: / /$ batamnews.co.id/berita-14331- inilah-syarat-memiliki-senjata-api-bagi-warga- sipil-di-indonesia.html, diakses tanggal 07 November 2018
${ }^{7}$ Anak Agung Ngurah Bayu Ariadi,Pertanggung jawaban pidana atas penylahgunaan senjata api, Jurnal Fakultas Hukum Universitas Udayana,2013, hal 11


Media Komunikasi dan Informasi Hukum dan Masyarakat

4. Penerapan

Kepemilikan

Hukum

Terhadap

Senjata

Angkatan POLRI dan TNI

Sebagian masyarakat di Indonesia berpendapat bahwa keamanan terhadap warga sipil masih belum maksimal sebagaimana mestinya, hal ini dapat di lihat sekarang banyak warga sipil yang memiliki senjata api. Bagi seseorang yang ingin menjaga keselamatan diri dengan memiliki senjata bukan lah suatu tindakan yang tidak baik. Sebab, kepemilikan senjata api itu telah diatur oleh Undang undang Nomor 12 tahun 1951 dan didukung Undang - undang Nomor 20 Prp tahun 1960 tentang kewenangan perizinan senjata api, tentang Kepolisian Republik Indonesia UndangUndang Nomor: 2 tahun 2002 menjelaskan di dalam Pasal 15 ayat 2 huruf e yakni Kepolisian memberikan izin dan melakukan pengawasan senjata api, bahan peledak, dan senjata tajam. Administrasi pada lembaga kepolisian dalam hal perizinan senjata api itu sendiri adalah bagian dari administrasi negara dan sistem kepolisian suatu negara sangat terpengaruh dan bergantung dari bagaimana sistem pemerintahan suatu negara itu sendiri berjalan. ${ }^{8}$

Selain itu, setelah menggunakan senjata api, polisi harus membuat laporan terperinci mengenai evaluasi pemakaian senjata api. Laporan tersebut berisi (Pasal 14 ayat (2) Perkapolri 1/2009). Laporan inilah yang akan digunakan untuk bahan pertanggungjawaban hukum penerapan penggunaan kekuatan, serta sebagai bahan pembelaan hukum dalam hal terjadi gugatan pidana/perdata terkait penggunaan kekuatan yang dilakukan oleh

${ }^{8}$ Awaloedin, Djamin.sistem Administrasi Kepolisian.(Jakarta:YPKIK,2011), hal 5 anggota Polri yang bersangkutan (Pasal 14 ayat

(5) huruf 3 dan $f$ Perkapolri 1/2009).

Pada prinsipnya, setiap anggota POLRI wajib bertanggung jawab atas pelaksanaan penggunaan kekuatan (senjata api) dalam tindakan kepolisian yang dilakukannya (Pasal 13 ayat (1) Perkapolri 1/2009).

\section{KEBIJAKAN HUKUM DALAM} PENANGANAN KEPEMILIKAN SENJATA API OLEH MASYARAKAT SIPIL

\section{Kitab Undang-Undang Hukum Pidana (KUHP)}

Kitab Undang-Undang Hukum Pidana membagi tindak pidana menjadi dua jenis yakni Kejahatan dan Pelanggaran. Delik-delik yang termasuk dalam kejahatan dimuat dalam Buku II dan yang termasuk pelanggaran dimuat dalam Buku III. Akan tetapi dalam KUHP tidak disebutkan kriteria apa yang dipergunakan untuk membedakan kedua jenis delik tersebut. Perbedaan antara pelanggaran dan kejahatan merupakan perbedaan antara delik Undangundang dan delik hukum.

Kejahatan merupakan delik hukum sedangkan pelanggaran merupakan delik Undang-undang, jadi kejahatan perbuatan karena sifatnya bertentangan dengan ketertiban hukum sedangkan pelanggaran adalah perbuatan yang oleh Undang-undang dicap sebagai suatu perbuatan yang bertentangan dengan ketertiban umum.

Menurut Sudarto, kriteria untuk membedakan kedua jenis delik tersebut di atas didasarkan atas pendapat sebagai berikut : bahwa antara kedua jenis delik ada perbedaan yang bersifat kualitatif. Kedua jenis delik yang 
Media Komunikasi dan Informasi Hukum dan Masyarakat

dimaksud kejahatan atau "Rechtdelicten" yaitu perbuatan yang bertentangan dengan keadilan, terlepas apakah perbuatan itu diancam pidana dalam suatu Undang-undang atau tidak. Sedangkan jenis delik yang kedua yaitu pelanggaran atau "wetsdelicten" ialah perbuatan yang oleh umum baru disadari sebagai suatu tindak pidana karena Undang-undang menyebutnya sebagai delik, jadi karena Undang-undang yang mengancamnya dengan pidana.

Menurut Sudarto, perbedaan secara kualitatif tidak dapat diterima, sebab ada kejahatan yang baru disadari sebagai delik karena tercantum dalam KUHP, jadi sebenarnya tidak dirasakan sebagai bertentangan dengan rasa keadilan dan sebaliknya ada pelanggaran yang memang benar-benar dirasakan bertentangan dengan rasa keadilan.

KUHP Indonesia menganut aliran monistis, yang mana di dalam aliran monistis tidak ada perbedaan antara tindak pidana, pertanggungjawaban pidana, namun dalam perkembangannya maupun dalam dunia praktek ada perbedaan tegas antara tindak pidana dan pertanggungjawaban pidana, sebagaimana hal tersebut di pertegas oleh Sudarto tentang pandangan monitis. Pandangan monistis adalah suatu pandangan yang melihat keseluruhan syarat untuk adanya pidana itu kesemuanya merupakan sifat dari perbuatan.

Pandangan ini memberikan prinsip-prinsip pemahaman, bahwa di dalam pengertian perbuatan/tindak pidana sudah tercakup di dalamnya perbuatan yang dilarang (criminal act) dan pertanggungjawaban pidana/kesalahan (criminal responbility).

Berbicara dalam hal dalam tindak Pidana, khususnya KUHP adanya pembagian antara kejahatan dan pelanggaran, yang mana kejahatan dan pelanggaran tersebut merupakan kualifikasi yuridis.

Menurut hukum pidana positif yang saat ini berlaku (yang berinduk pada KUHP), kualifikasi yuridis terdiri dari " kejahatan" dan "pelanggaran" seperti dalam KUHP (WvS) Belanda. Di dalam aturan umum Buku I KUHP ada perbedaan akibat/konsekuensi hukumnya antara kejahatan dan pelanggaran, antara lain dalam pembantuan, perbarengan/concursus, tengang waktu daluwarsa (daluwarsa penuntutan maupun pelaksanaan/eksekusi pidananya.

Adapun dalam ketentuan KUHP Indonesia menerangkan tentang Kepemilikan Senjata Api terdapat dalam Pasal 500 KUHP. Pada ketentuan KUHP tersebut tidak menerangkan di dalamnya kualifikasi yuridis kejahatan dan pelanggaran, karena kualifikasi yuridis antara kejahatan dan pelanggaran memiliki akibat yuridis yang berbeda pula, antara kejahatan dan pelanggaran dalam hal percobaan, pembantuan, penyertaan dan residive. Percobaan menurut pasal 54 terhadap pelanggaran tidak dapat di pidana, sedangkan pada pasal 53 ayat 3 percobaan terhadap kejahatan di pidana. ${ }^{9}$

Pertanggungjawaban pidana pada dasarnya bersifat individual dan dalam hal pemidanaan terikat pada asas kesalahan atau asas culpabilitas atau asas Green Straf Zonder Schuld atau Keine Strafe Ohne Schuld atau No punishment without fault, yang artinya badanbadan hukum tidak bisa melakukan tindak pidana. Menurut KUHP di Indonesia, hanya mengenal orang perseorangan sebagai pelaku

${ }^{9}$ https://fahum.unsam.ac.id/kebijakanformulasi-hukum-pidana-kepemilikan-senjataapi-ilegal-dalam-pembaharuan-hukum-pidanadi-indonesia, diakses tanggal 07 november 2018 
Media Komunikasi dan Informasi Hukum dan Masyarakat

tindak pidana dan korporasi bukan merupakan subyek hukum pidana. Hal ini dapat di lihat dari ketentuan Pasal 59 KUHP.

Badan-badan hukum tidak dapat melakukan tindak pidana dan yang bisa melakukan tindak pidana hanyalah manusia alamiah (natuurlijke persoon), sedangkan manusia hukum (rechts persoon) tidak dapat melakukan tindak pidana, namun dalam perkembangannya ternyata manusia alamiah bergabung satu sama lain membentuk suatu bidang usaha dalam bentuk suatu organisasi. Perkembangan ilmu pengetahuan dan teknologi juga menimbulkan kemajuan di bidang ekonomi sehingga muncul pelaku-pelaku usaha yang tidak hanya bersifat perorangan tetapi sudah dalam bentuk kerjasama berupa perkumpulan orang atau harta kekayaan dalam bentuk korporasi. Korporasi ini dalam melakukan kegiatannya sudah barang tentu berorientasi pada keuntungan. Oleh karena itu kemungkinan melakukan juga perbuatan yang dapat merugikan orang lain dalam mencapai tujuannya.

Di Indonesia, pengakuan korporasi sebagai subyek hukum pidana, saat ini pengaturannya hanya dapat ditemukan dalam perundang-undangan hukum pidana di luar KUHP ataupun perundang-undangan administrasi yang bersanksi pidana. Akan tetapi, masih ada terlihat ketidaktuntatasan pembentuk undang-undang (kebijakan formulasi) dalam merumuskan korporasi sebagai subyek hukum yang dapat dijatuhi pidana. Adapun ketidaktuntasan tersebut yaitu mengenai kapan suatu korporasi dianggap harus bertanggungjawab, ataupun bagaimana cara pertanggungjawabannya.

Konsekuensi yuridis dengan tidak diaturnya korporasi sebagai subyek tindak pidana dalam Buku I KUHP (sebagai ketentuan umum hukum pidana), yaitu pengaturannya dalam ketentuan undang-undang di luar KUHP menjadi sangat beraneka ragam. Misalnya, Undang-Undang Darurat No. 12 tahun 1951 tentang kepemilikan senjata api, amunisi, bahan peledak, dan senjata lain, hanya meminta pertanggungjawaban pidana kepada pengurusnya saja, sebagaimana diatur dalam Pasal 4 ayat (1).

KUHP merupakan sistem induk hukum pidana materiil yang tidak mengakui/tidak mengenal dapat di pertanggungjawabkannya korporasi secara pidana akan menimbulkan masalah yuridis sebagaimana di ketahui Undang-undang khusus yang memuat ketentuan pidana di luar KUHP yang merupakan sub sistem pidana materiil dalam perkembangannya mengakui bahwa korporasi sebagai subjek hukum dan dapat di pertanggungjawabkan secara pidana, namun sangat di sayangkan Undang-undang khusus yang memuat ketentuan pidana tersebut banyak yang tidak mencantumkan pedoman dan pemidanaan terhadap korporasi antara lain mencakup:

a. Penegasan korporasi sebagai subjek hukum tindak pidana

b. Penentuan sanksi pidana/tindakan untuk korporasi

c. Penentuan siapa yang dapat di pertanggungjawabkan

d. Penentuan kapan korporasi dapat di pertanggungjawabkan

e. Penentuan kapan pengurus dapat di pertanggungjawabkan

f. Penentuan alasan pembenar dan pemaaf bagi korporasi

g. Penentuan aturan/pedoman pemidanaan bagi korporasi 
Media Komunikasi dan Informasi Hukum dan Masyarakat

Hal tersebut dapat menimbulkan permasalahan yuridis karena KUHP yang merupakan sistem induk hukum pidana materiil sebagaimana yang di jelaskan di atas tidak mengenal pertanggungjawaban pidana bagi korporasi. Undang-undang Darurat No.12 tahun 1951 tentang senjata api, juga tidak mengatur tentang pertanggungjawaban bagi korporasi.

KUHP yang berlaku di Indonesia pada saat ini belum mengenal hal yang dinamakan pedoman pemidanaan. Oleh karena itu, hakim dalam memutus suatu perkara diberi kebebasan memilih jenis pidana (strafsoort) yang dikehendaki, sehubungan dengan sistem alternatif dalam pengancaman di dalam undangundang. Selanjutnya hakim juga dapat memilih berat ringannya pidana (strafmaat) yang akan dijatuhkan, sebab yang ditentukan oleh undangundang hanya maksimum dan minimum pidana.

Sehubungan dengan hal tersebut, maka yang sering menimbulkan masalah dalam praktek adalah mengenai kebebasan hakim dalam menentukan berat ringannya pidana yang diberikan. Hal ini disebabkan undang-undang hanya menentukan batas maksimum dan minimum pidananya saja. Sebagai konsekuensi dari masalah tersebut, akan terjadi hal yang disebut dengan disparitas pidana.

Pembaharuan dalam bidang substantive hukum ini diartikan sebagai upaya melakukan reformasi dan reevaluasi masalah pokok dalam Hukum pidana yaitu masalah menentukan dan menetapkan perbuatan yang dilarang/ tindak pidana masalah pertanggungjawaban pidana atau kesalahan dan masalah pidana dan pemidanaan.

Masalah pertama dan kedua (Tindak pidana dan Kesalahan) dalam berbagai kesempatan telah banyak menjadi topik pembahasan namun terhadap masalah ketiga yaitu pidana dan pemidanaan seolah menjadi anak tiri dalam pembicaraan hukum pidana, padahal pemidanaan ini memegang peranan penting dalam mencapai tujuan (Goal) dari hukum pidana.

Sistem Pemidanaan pada hakikatnya merupakan sistem kewenangan/ kekuasaan menjatuhkan pidana. Patut dicatat bahwa pengertian "pidana" tidak hanya dilihat dalam arti sempit/ formal, tetapi juga dapat dilihat dalam arti luas/ materiil. Dalam arti sempit/ formal, sistem pemidanaan berarti kewenangan menjatuhkan/ mengenakan sanksi pidana menurut Undang-undang oleh pejabat yang berwenang (hakim), dalam arti luas/ material, sistem pemidanaan merupakan suatu mata rantai proses tindakan hukum dari pejabat yang berwenang, mulai dari proses penyidikan, penuntutan, sampai pada putusan pidana dijatuhkan oleh pengadilan dan dilaksanakan oleh aparat pelaksana.

Hal ini dipertegas oleh Sudarto yang menyatakan : KUHP kita tidak memuat pedoman pemberian pidana (straftoemetingsleiddraad) yang umum ialah suatu pedoman yang dibuat oleh pembentuk undang-undang yang memuat asas-asas yang perlu diperhatikan oleh hakim dalam menjatuhkan pidana, yang ada hanya aturan pemberian pidana (straftoemetingsregels).

Dari pendapat di atas secara implisit menyatakan bahwa pedoman pemidanaan merupakan kebijakan legislatif yang "seharusnya" ada dalam aturan/ norma hukum pidana materiil yang harus diperhatikan dalam pemberian pidana. Tujuan dalam Kamus besar Bahasa Indonesia diartikan sebagai "arah, haluan (jurusan), maksud, tuntutan (yang dituntut)" 
Media Komunikasi dan Informasi Hukum dan Masyarakat

Tujuan pemidanaan berarti arah yang "seharusnya" ingin dicapai dari penjatuhan pidana atau dapat diartikan juga maksud yang hendak didapatkan dari pemberian pidana/pemidanaan. Tujuan pemidanaan mengemban fungsi pendukung dari fungsi hukum pidana secara umum yang ingin dicapai sebagai tujuan akhir adalah terwujudnya kesejahteraan dan perlindungan masyarakat (Social defence dan Social welfare)

Menetapkan tujuan dan pedoman pemberian pidana harus dijadikan pertimbangan hakim dalam menjatuhkan pidana sehingga keputusan hakim tersebut dapat terbaca oleh orang lain(masyarakat) dan khususnya oleh orang yang berkepentingan dalam perkara itu.

Hukum pidana tidak terlepas dari adanya sanksi yang berupa pidana, dalam pelajaran ilmu hukum pidana masalah pidana dan pemidanaan kurang mendapatkan perhatian seperti halnya perhatian terhadap dua masalah pokok lainnya dalam hukum pidana yaitu perbuatan/tindakan dan pertanggungjawaban/kesalahan. Pembahasan tentang stesel pidana tidak akan habis habisnya mengingat bahwa justru stesel pidana bagian yang terpenting dari suatu kitab undang-undang hukum pidana.

Berdasarkan ketentuan dalam Undangundang darurat No. 12 Tahun 1951 tentang kepemilikan senjata api, amunisi, bahan peledak, dan senjata lain, maka aturan pemidanaan (pidana mati, pidana penjara, denda serta kurungan), berlaku sama dengan aturan pemidanaan dalam KUHP, kecuali apabila ditentukan tersendiri dalam Undangundang darurat No. 12 Tahun 1951 tentang kepemilikan senjata api, amunisi, bahan peledak, dan senjata lain, maka aturan pemidanaan diberlakukan khusus (lex specialis derogat legi generalis).

Meskipun tindak pidana belum terlaksana tidak berarti permufakatan jahat sama dengan tindak pidana percobaan (poging) sebagaimana yang diatur dalam Pasal 53 KUHP. Dalam tindak pidana percobaan harus memenuhi 3 unsur yaitu niat, permulaan pelaksaan dan perbuatan tersebut tidak jadi selesai diluar kehendak pelaku. Apabila melihat rumusan tindak pidana permufakatan jahat, maka niat dalam permufakatan jahat telah dapat dihukum. Karena perbuatan persiapan (voorbereiding) dalam permufakatan jahat sendiri belum ada.

Pada Konsep KUHP Undang-undang khusus ini di dalam nya tidak memuat ketentuan pidana tentang melakukan tindak pidana dengan pemufakatan jahat atau apabila terjadi pengulangan tindak pidana (recidive), sehingga menimbulkan masalah sendiri karena aturan pemidanaan dalam KUHP tidak hanya di tujukan pada subjek yang melakukan tindak pidana melainkan kepada mereka yang melakukan pemufakatan jahat dan pengulangan (recidive)

\section{UU DARURAT NO 12 TAHUN 1951}

Hukum berfungsi sebagai perlindungan kepentingan manusia. Hukum menjadi berarti apabila perilaku manusia dipengaruhi oleh hukum dan apabila masyarakat menggunakan hukum sebagai pengendali perilakunya, penegakan hukum berkaitan erat dengan masalah kepatuhan hukum sebagai norma. Masalah penegakan hukum terletak pada upaya terbaik penegakkan hukum pidana materil sebagaimana ketentuan hukum pidana formil mampu menjadi pengawal dalam membingkai semangat dan tujuan hukum pidana meteril itu sendiri. Dalam banyak hal upaya penegakan hukum, tidak cukup hanya dilihat dari aspek 
Media Komunikasi dan Informasi Hukum dan Masyarakat

hukum saja agar dapat berjalan secara efektif, tetapi ada aspek lain yaitu aparat hukum dan kultur masyarakatnya. Yang menjadi persoalan utama bukanlah kemungkinan turut sertanya tugas penegak hukum atau kemauan mayoritas dalam badan yang berwenang menentukan sanksi hukuman tertinggi atau terakhir untuk menyelenggarakan kehendaknya, tetapi justru kepercayaan atau keyakinan, bahwa peraturan hukum harus dilaksanakan biarpun tanpa paksaan fisik.

Walaupun beratnya sanksi pidana yang terdapat dalam suatu undang-undang namun hal itu bukanlah salah satu faktor keberhasilan hukum pidana dalam menerapkan sanksinya. Seperti yang terdapat pada undang-undang tentang ketentuan penggunaan senjata api yang memiliki sanksi pidana yang berat. Namun hal itu tidak menyurutkan penggunaan senjata api oleh kalangan yang tidak berhak menggunakannya. Malah penggunaannya malah ditujukan untuk melukai aparat penegak hukum itu sendiri. ${ }^{10}$

Pengaturan tentang senjata api terdapat pada Undang-Undang Nomor 8 Tahun 1948, tentang pendaftaran dan pemberian izin kepemilikan senjata api dan Undang-Undang Darurat Nomor 12 Tahun 1951 yang Mengubah "Ordonnantietijdelijke Bijzondere Strafbepalingen" (STBL. 1948 No. 17) dan Undang-Undang Republik Indonesia Dahulu Nomor 8 Tahun 1948.

Dengan banyaknya senjata api ilegal yang berada di Indonesia menunjukkan bahwa kurangnya rasa kepedulian negara dalam wujud apresiasinya terhadap perlindungan warga

${ }^{10} \mathrm{https}: / /$ nofryhardi.wordpress.com/20 16/10/19/pengaturan-senjata-api-dalam-uuno-12-tahun-1951, diakses tanggal 07 November 2018 negara. Hal ini juga memperlihatkan bahwa tidak sinkronnya antara perbuatan dan sanksi dalam hukum pidana dimana perbuatan dan tindakan yang nyata-nyata telah dilarang dalam hukum pidana serta mempunyai sanksi pidana yang cukup berat namun masih juga terdapat pelanggaran. Menurut lawrence $M$. Friedman penegakan hukum yang tidak berjalan dengan semestinya disebabkan karena; 1. Faktor legal substance, dimana perundangundangan tidak tegas dalam menyatakan senjata apa yang diperbolehkan dan senjata apa yang tidak diperbolehkan untuk dimiliki masyarakat sipil.

2. Faktor legal structure, yaitu penerapan dari ketentuan perundang-undangan oleh aparat penegak hukum kurang berjalan maksimal karena berbagai faktor intern dan ekstern yang menyebakan kerugian bagi mereka sendiri

3. Faktor legal culture, partisipasi masyarakat dalam pelaporan penggunaan senjata api ilegal dianggap sebagai hal yang dapat mengancam diri mereka sendiri. Pengguna senjata api dianggap sebagai orang yang sangat berbahaya.

Penegakan hukum dewasa ini dapat dikatakan belum memenuhi harapan, bukan hanya karena masalah profesionalisme aparat penegak hukum yang dipertanyakan tetapi juga masalah peraturan perundang-undangan serta masalah ketersediaan sarana dan prasarana pendukungnya. Proses penegakan hukum tidak akan pernah terlepas dari upaya kebijakan politik kriminal, karena kebijakan kriminal atau upaya penanggulangan kejahatan itu merupakan bagian integral dari upaya perlindungan masyarakat (sosial defence) dan upaya pencapaian kesejahteraan masyarakat (social welfare). 
Media Komunikasi dan Informasi Hukum dan Masyarakat

Selain itu dalam Pasal 1 ayat (1) dan Pasal 2 ayat (1) Undang-Undang Darurat Nomor 12 Tahun 1951 yang Mengubah "Ordonnantietijdelijke

Bijzondere Strafbepalingen" (STBL. 1948 No. 17) dan Undang-Undang Republik Indonesia Dahulu Nomor 8 Tahun 1948 (“UU Darurat 12/1951”).

Walaupun sanksi pidana yang terdapat dalam Undang-Undang Darurat Nomor 12 Tahun 1951 sangat berat namun ketentuan pidana dalam undang-undang tersebut dirasa kurang efektif dalam meminimalisir penyalahgunaan senjata api terutama dalam hal krisis penegakan hukun pada saat sekarang ini. Masalah penegakan hukum tidak bisa dilepaskan dari efektivitas hukum. Masalah efektivitas hukum berhubungan erat dengan usaha yang dilakukan agar hukum itu benarbenar hidup dalam masyarakat, dalam artian berlaku secara filosofis, yuridis dan sosiologis. Seacara filosofis, berarti bahwa hukum itu berlaku sebagaimana yang dikehendaki, berlaku secara yuridis artinya sesuai dengan apa yang telah dirumuskan dan berlaku secara sosiologis maksudnya hukum itu dipatuhi oleh warga masyarakat tersebut.

Para pelaksana atau para penegak hukum tidak memberikan contoh yang baik dalam kepatuhan terhadap hukum. Kepatuhan terhadap hukum seharusnya dicontohkan dengan baik oleh penegak hukum namun yang terjadi malah sebaliknya. Arogansi yang dilakukan oleh penegak hukum menjadi contoh yang buruk bagi masyarakat, terutama dengan penggunaan senjata api dalam penyelesaian konflik terhadap pelanggar hukum, pemilik kewenangan lain yang juga menggunakan senjata api maupun dengan sesama instansi sendiri.
Kepemilikan senjata api diatur secara implisit dalam undang-undang agar tidak terjadi penyalahgunaan terhadap senjata tersebut. Dalam undang-undang disebutkan bahwa ijin kepemilikan senjata api hanya diberikan kepada pejabat tertentu, antara lain ;

a. Pejabat swasta atau perbankan, yakni presiden direktur, presiden komisaris, komisaris, diretur utama dan direktur keuangan.

b. Pejabat pemerintah, yakni Menteri, Ketua MPR/DPR, Sekjen, Irjen, Dirjen, dan Sekretaris Kabinet, demikian juga Gubernur, Wakil Gubernur, Sekwilda, Irwilprop, Ketua DPRD-I dan Anggota DPR/MPR, TNI, Polri dan Purnawirawan.

Selain itu berdasarkan Pasal 15 ayat (2) huruf e Undang-Undang No. 22 Tahun 2002 tentang Kepolisian Negara Republik Indonesia, Kepolisian Negara Republik Indonesia berwenang untuk memberikan izin dan melakukan pengawasan senjata api, bahan peledak, dan senjata tajam.[9] Selain pengaturan tersebut, berdasarkan Pasal 7 ayat (1) Peraturan Menteri Pertahanan Republik Indonesia No. 7 Tahun 2010 tentang Pedoman Perizinan, Pengawasan dan Pengendalian Senjata Api Standar Militer Di Luar Lingkungan Kementerian Pertahanan Dan Tentara Nasional Indonesia ("Permenhan 7/2010"), untuk ekspor, impor pembelian, penjualan, produksi, pemilikan, penggunaan, penguasaan, pemuatan, pembongkaran, pengangkutan, penghibahan, peminjaman, pemusnahan senjata api standar militer dan amunisinya diperlukan izin Menteri.

Izin tersebut dapat diberikan dengan pembatasan-pembatasan tertentu sesuai tugas pokok dan fungsi kepada (Pasal 7 ayat [4] Permenhan 7/2010): 
Media Komunikasi dan Informasi Hukum dan Masyarakat
a) instansi pemerintah non Kemhan dan $\mathrm{TNI}$;
b) badan hukum nasional Indonesia tertentu;
c) perorangan (pejabat pemerintah tertentu; atlet menembak; kolektor);
d) kapal laut Indonesia; dan
e) pesawat udara Indonesia

\section{PERTIMBANGAN HAKIM DALAM MEMBERIKAN PUTUSAN TERHADAP TINDAK PIDANA SENJATA API DALAM PUTUSAN NO 79/PID.B/2016/PN.BLG}

Kasus yang penulis teliti ini merupakan kasus tanpa hak memiliki, membawa dan/atau menyimpan senjata api rakitan yang dilakukan oleh terdakwa yang bernama Ependi als Ipen.

\section{Posisi Kasus}

Pengadilan Negeri Balige yang memeriksa dan mengadili perkara pidana pada pengadilan tingkat pertama dengan acara pemeriksaan biasa telah menjatuhkan putusan sebagai berikut dalam perkara terdakwa Nama Ependi Als Ipen; tempat lahir Pantai Labu; umur 34 tahun: jenis kelamin laki-laki; kebangsaan Indonesia, tempat tinggal Dusun IV, Desa Sarang Burung, Kecamatan Pantai Labu, Kabupaten Deli Serdang; Agama Islam; pekerjaan Supir.

Bahwa dia terdakwa Ependi Als Ipen pada hari Jumat tanggal 04 Maret 2016 sekira pukul $02.30 \mathrm{Wib}$ atau setidak-tidaknya pada waktu lain dalam bulan Maret 2016 bertempat di depan Polsek Lumban Julu Kec. Lumban Julu Kab. Tobasa atau setidak-tidaknya pada suatu tempat lain yang masih termasuk dalam daerah hukum Pengadilan Negeri Balige, yang tanpa hak memasukkan ke Indonesia, membuat, menerima, mencoba memperoleh, menyerahkan atau mencoba menyerahkan, menguasai, membawa, mempunyai persedian padanya atau mempunyai dalam miliknya, menyimpan, mengangkut, menyembunyikan, mempergunakan atau mengeluarkan dari Indonesia sesuatu senjata api, amunisi atau sesuatu bahan peledak. Perbuatan mana dilakukan oleh terdakwa.

Bahwa pada waktu dan tempat sebagaimana yang tersebut diatas para saksi lqbal Daulay dan Eko Valentino Sitinjak sedang melaksanakan razia di depan Polsek Lumban Julu, Kec.Lumban Julu, Kab.Tobasa, kemudian terdakwa yang duduk di sebelah supir berangkat dari Pantai Labu Kab. Deli Serdang menuju Sibolga dengan mengendarai 1 (satu) Unit Mobil Mitsubishi Jenis L. 300 BK 8251 MP untuk membawa barang dagangan berupa telur milik tokenya yang bernama Suwanto Halim (DPO) untuk dijual ke Sibolga, dimana sebelum berangkat menuju Sibolga maka Suwanto Halim memberikan 1 (satu) Unit Senjata Airgun Handgun Jenis WG Nomor 99MO1044 beserta 8 (delapan) butir peluru mimis kepada terdakwa untuk berjaga-jaga apabila ada perampok yang akan merampok terdakwa. Selanjutnya mobil yang ditumpangi oleh terdakwa distop petugas kepolisian, kemudian petugas kepolisian menanyakan "Apa isi tas "lalu terdakwa menjawab "Senjata Pak" sehingga petugas kepolisian langsung menangkap terdakwa yang tidak dapat menunjukkan Surat ljin Rekomendasi dari Kapolda Sumatera Utara atau Kapolres Tobasa. Seterusnya petugas kepolisian membawa terdakwa bersama barang buktinya berupa 1 (satu) Unit Senjata Airgun / Handgun Jenis WG Nomor 99MO1044, 8 (delapan) butir peluru mimis, 1 (satu) buah tabung gas kecil warna putih dengan tulisan 
Media Komunikasi dan Informasi Hukum dan Masyarakat

warna merah, 1 (satu) buah kartu registrasi unit atas nama Suwanto Halim,1 (satu) buah kartu registrasi anggota atas nama Suwanto Halim dan 1 (satu) buah tas sandang merk Polo Renzi warna coklat ke kantor Polres Tobasa untuk dilakukan pemeriksaan lebih lanjut.

\section{Dakwaan}

Bahwa pada waktu dan tempat sebagaimana yang tersebut diatas para saksi lqbal Daulay dan Eko Valentino Sitinjak sedang melaksanakan razia di depan Polsek Lumban Julu Kec. Lumban Julu Kab. Tobasa, kemudian terdakwa yang duduk di sebelah supir berangkat dari Pantai Labu Kab. Deli Serdang menuju Sibolga dengan mengendarai 1 (satu) Unit Mobil Mitsubishi Jenis L. 300 BK 8251 MP untuk membawa barang dagangan berupa telur milik tokenya yang bernama Suwanto Halim (DPO) untuk dijual ke Sibolga, dimana sebelum berangkat menuju Sibolga maka Suwanto Halim memberikan 1 (satu) Unit Senjata Airgun / Handgun Jenis WG Nomor 99MO1044 beserta 8 (delapan) butir peluru mimis kepada terdakwa untuk berjaga-jaga apabila ada perampok yang akan merampok terdakwa. Selanjutnya mobil yang ditumpangi oleh terdakwa distop petugas kepolisian, kemudian petugas kepolisian menanyakan apa isi tas lalu terdakwa menjawab Senjata Pak, sehingga petugas kepolisian langsung menangkap terdakwa yang tidak dapat menunjukkan Surat ljin Rekomendasi dari Kapolda Sumatera Utara atau Kapolres Tobasa. Seterusnya petugas kepolisian membawa terdakwa bersama barang buktinya berupa 1 (satu) Unit Senjata Airgun Handgun Jenis WG Nomor 99MO1044, 8 (delapan) butir peluru mimis, 1 (satu) buah tabung gas kecil warna putih dengan tulisan warna merah, 1 (satu) buah kartu registrasi unit atas nama Suwanto Halim,1 (satu) buah kartu registrasi anggota atas nama Suwanto Halim dan 1 (satu) buah tas sandang merk Polo Renzi warna coklat ke kantor Polres Tobasa untuk dilakukan pemeriksaan lebih lanjut.

Berdasarkan hasil Pemeriksaan Laboratoris Kriminalistik Polri Cabang Medan No. LAB 2688/BSF/2016 tanggal 16 Maret 2016 yang dibuat dan ditanda tangani oleh Binsaudin Saragih, S.Si.M.Si dan Supriyadi, ST dengan hasil pemeriksaan terhadap barang bukti sebagai berikut :

a. Terhadap 1 (satu) Pucuk Senjata Airsoft Gun (BB1)

Setelah dilakukan pemeriksaan secara certmat dan teliti, ternyata barang bukti tersebut adalah Senjata Airsoft Gun dalam keadaan berfungsi dengan baik (aktif) dan diperoleh identitas sebagai berikut :

1. Jenis Senjata : Airsoft Gun Replika Jenis Pistol
2. Merek/Model
:WG
3. Nomor Seri : $99 \mathrm{MO} 1044$
4. Panjang Laras
$: 8,3 \mathrm{~cm}$
5. Panjang Senjata
$: 20,5 \mathrm{~cm}$
6. Diameter Laras
: $6 \mathrm{~mm}$

b. Terhadap 8 (delapan) butir Gotri/Mimis (BB2)

Setelah dilakukan pemeriksaan secara cermat dan teliti, ternyata barang bukti tersebut adalah Gotri/Mimis dalam keadaan baik dan diperoleh identitas sebagai berikut :
1. Bahan
: Logam
2. Diameter
: $6 \mathrm{~mm}$
3. Berat per butir $: 0,8814 \mathrm{gr}$

c. Terhadap 1 (satu) buah Magazen Senjata Airsoft Gun (BB3) 
Media Komunikasi dan Informasi Hukum dan Masyarakat

Setelah dilakukan pemeriksaan secara cermat dan teliti, ternyata barang bukti tersebut adalah Magazen dari Senjata Airsoft Gun (BB1) berisikan tabung gas $\mathrm{CO}_{2}$ yang berfungsi sebagai tenaga pendorong peluru dalam keadaan berisi dan diperoleh identitas sebagai berikut :

1. Jenis

: Gas $\mathrm{CO}_{2}$

2. Diameter botol

: $1,87 \mathrm{~mm}$

3. Panjang botol

$: 8,33 \mathrm{~cm}$

4. Dimensi botol : $12,2 \mathrm{~cm} \times 3,18$ $\mathrm{cm} \times 1,9 \mathrm{~cm}$

d. Terhadap 1 (satu) buah Tabung Gas $\mathrm{CO}_{2}$ (BB4)

Setelah dilakukan pemeriksaan secara cermat dan teliti, ternyata barang bukti tersebut adalah Tabung Gas $\mathrm{CO}_{2}$ yang berfungsi sebagai tenaga pendorong peluru dalam keadaan kosong dan diperoleh identitas sebagai berikut :

1. Jenis

: Gas $\mathrm{CO}_{2}$

2. Diameter botol

: $1,87 \mathrm{~mm}$

3. Panjang boto

$: 8,33 \mathrm{~cm}$

4. Dimensi botol $: 12,2 \mathrm{~cm} \times 3,18$ $\mathrm{cm} \times 1,9 \mathrm{~cm}$

\section{Tuntutan Jaksa Penuntut Umum}

Setelah mendengar tuntutan dari Jaksa Penuntut Umum yang diajukan di persidangan pada hari Senin tanggal 23 Mei 2016 yang pada pokoknya mohon kepada Hakim yang memeriksa dan mengadili perkara ini memutuskan ;

a. Menyatakan Terdakwa Ependi Als Ipen telah terbukti secara sah dan meyakinkan bersalah melakukan tindak pidana tanpa hak membawa senjata api sebagaimana diatur dan diancam pidana dalam pasal 1 ayat (1) UU Darurat No 12 tahun 1951 tentang mengubah ordonan tietijdelijke bijzondere strafbepalingen
(STBL 1948 nomor 17) dan Undang undang Republik Indonesia dahulu Nomor 8 tahun 1948

b. Menjatuhkan pidana terhadap Terdakwa Ependi Als Ipen berupa pidana penjara selama 5 (lima) bulan penjara dengan dikurangi selama terdakwa berada dalam tahanan sementara

c. Menyatakan barang bukti berupa :

- 1 (satu) Unit Air Gun Jenis WG Nomor 99MO1044

- 1 (satu) buah Kartu registrasi unit atas nama Suwanto Halim

- 1 (satu) buah Kartu registrasi anggota atas nama Suwanto Halim

- 8 (delapan) butir peluru mimis yang terbuat dari timah

- 1 (satu) buah tas sandang merek Polo Renzi warna coklat

- 1 (satu) buah tabung gas kecil warna putih dengan tulisan warna merah

d. Masing masing dirampas untuk dimusnakan .

e. Menetapkan agar Terdakwa membayar biaya perkara sebesar Rp.2.000. (dua ribu rupiah)

\section{Pertimbangan dan Putusan Hakim}

Berdasarkan pertimbangan hakim dalam memutus perkara tindak pidana kepemilikan senjata api tanpa hak, adalah sebagai berikut :

1. Menimbang, bahwa berdasarkan fakta hukum tersebut diatas perbuatan Terdakwa yang membawa senjata api air soft gun tersebut di atas yang diberikan oleh Suwanto Halim (DPO) dengan maksud untuk menjaga-jaga apabila terjadi perampokan terhadap Terdakwa, dimana Terdakwa tidak memiliki izin untuk membawa senjata api air soft gun 
Media Komunikasi dan Informasi Hukum dan Masyarakat

tesebut, maka perbuatan Terdakwa tersebut merupakan perbuatan tanpa hak membawa senjata api;

2. Menimbang, bahwa dengan terpenuhinya seluruh unsur-unsur dari dakwaan tunggal, maka majelis hakim telah memperoleh keyakinan dan bukti yang tidak terbantahkan lagi bahwa Terdakwa benar telah melakukan perbuatan sebagaimana yang telah didakwakan kepadanya yaitu melanggar dakwaan tunggal;

3. Menimbang, bahwa karena Terdakwa terbukti melakukan perbuatan sebagaimana yang telah didakwakan Penuntut Umum dalam dakwaan tunggal, sedangkan majelis hakim tidak menemukan adanya alasan pemaaf maupun alasan pembenar yang dapat mengecualikan dan menghapuskan pemidanaan atas diri maupun perbuatan Terdakwa, maka Terdakwa haruslah dinyatakan telah terbukti secara sah dan meyakinkan bersalah melakukan tindak pidana sebagaimana dalam dakwaan tunggal Penuntut Umum dan Terdakwa haruslah dijatuhi pidana yang setimpal dengan perbuatannya dan kesalahannya;

4. Menimbang, bahwa pidana yang akan dijatuhkan kepada Terdakwa lebih lama dari masa penahanan yang telah dijalani oleh Terdakwa, serta tidak ditemukannya alasan untuk mengeluarkan Terdakwa dari tahanan, maka adalah patut untuk memerintahkan Terdakwa tetap berada dalam tahanan;

5. Menimbang, bahwa mengenai barang bukti yang diajukan dipersidangan, maka status barang bukti tersebut akan ditetapakan dalam amar putusan;
6. Menimbang, bahwa sesuai dengan ketentuan yang terkandung dalam ketentuan Pasal 222 Ayat (1) KUHAP yang menegaskan bahwa siapapun yang dijatuhi pidana haruslah dibebani untuk membayar biaya perkara dan oleh karena dalam hal ini Terdakwa dijatuhi pidana, maka terhadapnya haruslah dibebani untuk membayar biaya perkara

7. Menimbang, bahwa untuk memenuhi rasa keadilan, maka majelis hakim akan mempertimbangkan hal-hal yang memberatkan dan meringankan yang ada pada diri Terdakwa sebagai berikut:

Hal-hal yang memberatkan :

- Bahwa perbuatan Terdakwa dapat meresahkan masyarakat;

- Bahwa Terdakwa dapat menyalahgunakan senjata api untuk berbuat kejahatan;

Hal- hal yang meringankan :

- Bahwa Terdakwa mengakui perbuatannya, merasa bersalah dan menyesali perbuatannya;

- Bahwa Terdakwa belum pernah di hukum;

8. Menimbang, bahwa berdasarkan pertimbangan-pertimbangan hukum tersebut di atas dan hal hal yang memberatkan dan meringankan yang ada pada diri Terdakwa maka adil bagi Terdakwa dihukum sesuai dengan kesalahannya dan perbuatannya sebagaimana yang akan disebutkan dalam amar putusan;

9. Mengingat, Pasal 1 Ayat

UU.Drt.Nomor 12 Tahun 1951 Tentang Senjata Api, UU.No.48 Tahun 2009 Tentang Kekuasan Kehakiman, UU.No.49 Tahun 2009 Tentang Perubahan Kedua 
Media Komunikasi dan Informasi Hukum dan Masyarakat

atas UU.Nomor 2 Tahun 1986 Tentang

Peradilan Umum, Undang-Undang Nomor

8 Tahun 1981 tentang KUHAP, serta peraturan lain yang berkaitan dengan perkara ini;

\section{Mengadili}

1) Menyatakan Terdakwa Ependi Als.Ipen, telah terbukti secara sah dan meyakinkan bersalah melakukan tindak pidana "Tanpa hak dan melawan hukum membawa senjata api";

2) Menjatuhkan pidana kepada Terdakwa Ependi Als.Ipen oleh karena itu dengan pidana penjara selama 3 (tiga) bulan;

3) Menetapkan bahwa masa penahanan yang telah dijalankan oleh Terdakwa dikurangkan seluruhnya dari pidana yang dijatuhkan;

4) Menetapkan agar Terdakwa tetap berada dalam tahanan;

5) Menetapkan barang bukti berupa:

- 1 (satu) unit Airgun atau Handgun jenis WG Nomor 99 M01044;

- 1 (satu) buah kartu registrasi unit atas nama Suwanto Halim;

- 1 (satu) buah kartu registrasi anggota atas nama Suwanto Halim;

- 8 (delapan) butir peluru mimis yang terbuat dari timah;

- 1 (satu) buah tas sandang merek Polo Renzi warna coklat;

- 1 (satu) buah tabung gas kecil warna putih dengan tulisan warna merah;

Masing-masing dirampas untuk dimusnahkan;

6) Membebankan biaya perkara kepada Terdakwa sebesar Rp.2.000,- (dua ribu rupiah);

\section{Analisis Kasus}

Hakim dalam menjatuhkan putusan harus mempertimbangkan hal-hal yang meringankan maupun yang memberatkan terdakwa. Dalam kasus Ependi Als Ipen dimana terdakwa telah terbukti secara sah menyakinkan menurut hukum bersalah melakukan tindak pidana," Tanpa Hak memasukkan ke Indonesia, membuat, menerima, mencoba memperoleh, menyerahkan atau mencoba menyerahkan, menguasai, membawa, mempunyai persediaan padanya atau mempunyai dalam miliknya, meyimpan, mengangkut, menyembunyikan, mempergunakan atau mengeluarkan dari Indonesia sesuatu senjata api, amunisi atau sesuatu bahan peledak. Hakim hanya menjatuhkan kepada terdakwa Ependi Als Ipen dengan pidana penjara selama 3 (tiga) bulan, penulis tidak setuju dengan putusan hakim tersebut dimana tuntutan Jaksa Penuntut Umum kepada terdakwa Ependi Als Ipen di pidana selama 5 (lima) bulan dikurangi selama terdakwa dalam tahanan. Dalam UU Darurat No 12 Tahun 1951 disebutkan hukuman masksimal terhadap kepemilikan senjata api tanpa izin adalah maksimal hukuman mati, hukuman seumur hidup dan 20 tahun penjara.

\section{KESIMPULAN}

Berdasarkan pemaparan di atas, maka dapat disimpulkan hal-hal sebagai berikut :

1. Penerapan hukum mengenai kepemilikan senjata api oleh masyarakat sipil, diatur dalam Undang-Undang Nomor 8 tahun. Surat Keputusan Kapolri :Skep/82/II/2004, dan ketentuan pidana Pasal 1 ayat (1) Undang-undang 12 Tahun 1951.

2. Kebijakan hukum pidana khususnya mengenai tindak pidana kepemilikan 
Media Komunikasi dan Informasi Hukum dan Masyarakat

senjata api ilegal saat ini memiliki sejumlah kelemahan yang mendasar, sehingga berpengaruh pada tingkat efektivitas terhadap pelaksanaan pemberantasan tindak pidana kepemilikan senjata api ilegal, kelemahan dalam tahap formulasi (in abstracto) merupakan kelemahan strategis bagi tahap berikutnya yaitu tahap aplikasi dan eksekusi (in concret).

3. Hakim dalam memutus perkara terhadap terdakwa kepemilikan senjata api (Studi Putusan No. 79/Pid.B/2016/PN-Blg) yakni terdakwa Ependi Als Ipen terseut oleh karena itu dengan pidana penjaraelama 3 (tiga) bulan. Penulis tidak setuju engan putusan hakim tersebut dimana tntutan Jaksa Penuntut Umum kepada tedakwa dipidana selama 5 (lima) bulan durangi selama terdakwa dalam tahananDalam Undang-undang Darurat No 12Tahun 1951 disebutkan hukuman maksimal terhadap kepemilikan senjata api tanpa izin adalah maksimal hukuman mati, hukuman seumur hidup dan 20 tahun penjara.

\section{DAFTAR PUSTAKA}

\section{Buku Buku}

Anak Agung Ngurah Bayu Ariadi,Pertanggung Jawaban Pidana Atas Penyalahgunaan Senjata Api, Jurnal Fakultas Hukum Universitas Udayana, 2013

Awaloedin, Djamin.sistem Administrasi Kepolisian.(Jakarta:YPKIK,2011)

Barda Nawawi Arif , Sari Kuliah Hukum Pidana II. Fakultas Hukum Undip.1984

H. Hari Saherodji, Pokok-pokok Kriminiologi, Aksara Baru, Jakarta

P.A.F. Lamingtan, 1996, Dasar-Dasar Hukum Pidana Indonesia. PT. Citra Aditya Bakti, Bandung.
Rahmat, Jalaludin. 2004. Metode Penelitian Komunikasi, Bandung: cv.Remaja Rosdakarya

Satjipto Raharjo, 2005. Masalah Penegakan Hukum Suatu Tinjauan Sosiologis, Sinar Baru, Bandung

Soerjono Soekanto.Faktor-faktor Yang Mempengaruhi Penegakan Hukum. Jakarta. Rineka Cipta.1986.

\section{Website :}

Http://batamnews.co.id/berita-14331-inilahsyarat-memiliki-senjata-api-bagiwarga-sipil-di-indonesia.html

Https://fahum.unsam.ac.id/kebijakan-forlasihukum-pidana-kepemilikan-senjat-apiilegal-dalam-pembaharuan-hukumidana-di-indonesia

Https://nofryhadi.wordpress.com/2016/10/1 9/pengatura-senjata-api-dalam-uu-no12-tahun-1951.

\section{Perundang-undangan}

Kitab Undang-Undang Hukum Pidana (KUHP), Undang-Undang Nomor 12 tahun 1951 Tentang pengaturan senjata api,

UU No. 2 Tahun 2002 tentang Kepolisian Negara Republik Indonesia,dan

Skep Kapolri No. Pol: Skep / 82 / II / 2004 tentang Pelaksanaan Pengawasan dan Pengendalian Senjata Non Organik TN/ POLRI 